\title{
Role of Agriculture in Reducing Consumption Expenditure in Nigeria
}

\author{
Cordelia Onyinyech Omodero ${ }^{1} \&$ Amah Kalu Ogbonnaya ${ }^{1}$ \\ ${ }^{1}$ Michael Okpara University of Agriculture Umudike, Umuahia, Abia State, Nigeria \\ Correspondence: Cordelia Onyinyech Omodero, Michael Okpara University of Agriculture Umudike, Umuahia, \\ Abia State, Nigeria.
}

Received: October 2, 2018

Accepted: November 24, 2018 Online Published: November 26, 2018

doi:10.5539/jms.v8n4p130

URL: https://doi.org/10.5539/jms.v8n4p130

\begin{abstract}
There is a general consensus that agriculture as an economic sector has contributed so much to the well-being of the Nigerian people, this understanding is without a thorough evaluation of the specific sub-sectors of agriculture and their individual contribution especially in reducing the cost of living in the country. This study tries to investigate the role of the four sub-sectors of agriculture in Nigeria in reducing consumption expenditure. The study employed time series data which covered a period from 1981-2017 and were obtained from CBN Statistical Bulletin, 2017 edition. The data were collected on the four agriculture sub-sectors which include: crop production, fishing, forestry and livestock (being the independent variables) and on consumer price index (dependent variable) used as proxy for consumption expenditure. The Ordinary Least Squares (OLS) method of multiple regression analysis was used to analyze the data. The findings revealed that crop production and livestock farming have significant positive impact on consumption expenditure while fishing had insignificant negative impact, then forestry had significant negative impact on CPI. The implication is that fishing and forestry farming require more investment to contribute positively to the Nigerian economy. Therefore, the study has suggested among others that the government should provide adequate funding for agriculture sub-sectors through access to bank facilities with less difficulty on the part of the farmers.
\end{abstract}

Keywords: agriculture, crop production, fishing, forestry, livestock farming, consumer price index

\section{Introduction}

Agriculture comprises all aspect of crop production, fisheries, forestry and livestock farming. The economic value of agriculture in an economy cannot be overestimated. First, it provides food to consumers and fibers for domestic industry; second, it is a source of scarce foreign exchange earnings; and third, it provides a market for industrial goods (Nazish, Iqbal \& Ramzan, 2013). Cost of living in Nigeria has been a very big challenge as many families cannot afford to feed properly and even to pay their bills. The role of agriculture in reducing cost of living in the country is necessary to be determined. Agriculture is embarked upon in the ancient days primarily for subsistence while the secondary purpose is to earn income. Since, the two reasons have remained the focus even in these modern times, it is thus, strongly believed that agriculture can reduce consumption expenditure in the country. The common understanding is that, there will be enough food supplies both for self-consumption and for commercial purposes, thus cost of food will be highly affordable by everyone thereby leading to 'zero hunger' in the country. However, the object of agriculture has changed from self-consumption only to commercialization and this is called economic operation in agriculture (Syed, Yasir, \& Farhan, 2012). As a result, the concept of self-sufficiency in agriculture has been transformed into profit maximization since farming supplies are no longer for individual benefits only but also for commercial purposes too.

The four types of agriculture in Nigeria include: crop production, fishing, forestry and livestock farming. Crop production is a branch of agriculture that deals with growing crops for use as food and fiber. Crop production includes grains, cotton, tobacco, fruits, vegetables, nuts, and plants. In Nigeria, the eleven (11) lucrative crop farming and production include rice production, tomato farming, plantain farming, vegetable farming, cassava farming, maize farming, beans farming, potatoes farming, soy beans production and cucumber farming (Steve, 2017).

Crop production is the most widely practiced agriculture in Nigeria. Crop farming in Nigeria has positive impact on the Nigeria economy through provision of food and employment. It also contributes reasonably to the real gross domestic product (RGDP). Though there are major limitations which include: low capital, unavailability of 
lands, lack of access to modern tools and government funding, spread of crop diseases due to no proper education on modern farming techniques (Steve, 2017).

Livestock is another large subsector of agriculture in Nigeria. Livestock farming in Nigeria comprises poultry farming, cattle rearing, fish farming, goat farming, honeybees farming, rabbit farming, snail farming, pig farming, grass cutters, sheep and dog breeding. Livestock farming in Nigeria is an important source of cash income for farmers and a good source of protein for consumers. It is one of the most sustainable means of food production in Nigeria. People love to eat and use meat to prepare various dishes as a result, the demand for livestock produce in the country is high. However, the challenge of improper handling of the farms remains an inherent risk. Farmcrowdy (2018) submits that, if the farmers lack adequate expertise in handling the livestock, there could be death of animals, high cost of feeding and maintenance.

Fish is an important dietary element and one of the few sources of animal protein available to many Nigerians. Fishing is carried on in Nigeria's many rivers, creeks, lagoons and lakes. Both Federal and State governments encourage the development of local fisheries, inland and at sea through research funding, providing training in improved fish culture and stocking reservoirs (Nations Encyclopedia, 2018). Fish farming in Nigeria has the challenges of inadequate space for growth, lack of power supply, clean water source and fish feed etc. (Agun, 2016).

Forestry products in Nigeria include: industrial round wood, sawn wood, wood based panels, particle board, pulp and paper, fuel wood and charcoal, wildlife and tourism. The Nigerian forests support a wide range of forest industries, both formal and informal sub-sectors. A vast majority of the Nigerian populace depend on these industries, thereby placing a lot of pressure on the forest resources of the nation. The Federal Department of Forestry in Nigeria has noted the depletion in Nigeria's forest estate due to so many factors such as bush burning, over grazing of forest lands, drought and flooding (Food and Agriculture Organization, 2018b).

Agriculture in Nigeria has been neglected for several decades after the discovery of oil resources. However, being the primary source of sustenance to every household in the country, there is need to investigate its contribution to 'zero hunger' through consumption expenditure reduction. The study seeks to use the four major sub-sectors of agriculture in Nigeria to determine its performance in reducing the cost of living which serves as a major contribution to the nation's economic growth, because high cost of living accelerates the rate of poverty and hunger in the country.

\subsection{Objective of the Study}

The major objective of the study is to investigate the role of agriculture in reducing the cost of living in Nigeria (using consumer price index as proxy). The study also seeks to pursue the following specific objectives:

1) To determine the influence of crop production (CPN)on consumer price index (CPI);

2) To assess the impact of fishing (FSG) on CPI;

3) To evaluate the effect of forestry (FSY) on CPI;

4) To establish the contribution of livestock (LSK) farming on CPI.

\subsection{Hypotheses}

In order to achieve the above objectives, the following null hypotheses were formulated:

Ho1: There is no significant relationship between crop production and CPI;

Ho2: Fishing in Nigeria does not impact significantly on CPI;

Ho3: Forestry does not have significant influence on CPI;

Ho4: Livestock farming does not affect CPI significantly. 


\section{Literature Review}

\subsection{Conceptual Framework}

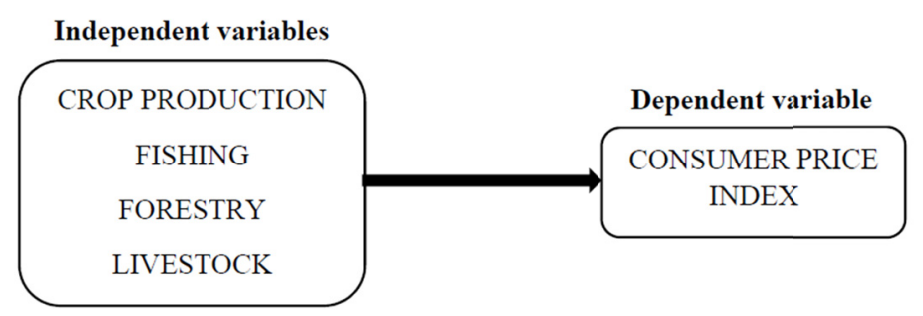

Figure 1. Agriculture subsectors and consumer price index

Source: Desk Research, 2018.

\subsubsection{Concept of Agriculture Subsectors and Consumer Price Index}

Consumer price index (CPI) reflects changes in the cost to average consumer of acquiring a basket of goods and services that may be fixed or changed at specific intervals, such as yearly (IMF, 2017). CPI is a comprehensive measure used for estimation of price changes in a basket of goods and services representing consumption expenditure in an economy (The Economic Times, 2018).

Agriculture comprises a whole lot of activities that practically and naturally reduce cost of living in an economy. International Standard Industrial Classification (ISIC) classifies agriculture under crop production, fishery, forestry, hunting and livestock (United Nations, 2008). Crop production is a branch of agriculture that deals with growing crops for food and in a commercial quantity (Steve, 2017). Using this definition as a basis, then sufficient crop production in a nation would have the tendency to reduce the cost at which a consumer obtains a basket of food. By so doing, agriculture can improve an economy of a nation through reduction in the cost of food.

Fishery may involve the capture of wild fish or raising fish through fish farming or aquaculture (FAO, 2018a; NOAA, 2006). Fishery is a term that defines all fishery activities as regards the people involved (fishers), species of fish, water area, fishing method among others (Food and Agriculture Organization, 2018a). Fisheries are harvested for their value, be it commercial, recreational or self-consumption. Fisheries can be captured from salt water or freshwater; they may also be wild or farmed. Most fisheries are wild fisheries, but for the purpose of increasing demand for fisheries, there are also farmed fisheries majorly carried out in coastal areas, lakes, ponds and tanks (FAO, 2018a). The whole aim is to keep demand and supply for fish at equilibrium and to minimize the cost of consumption.

Forestry is the science and craft of creating, managing, using, conserving, and repairing forests, woodlands, and associated resources to meet desired goals, needs, and values for human and environment benefits (Society of American Foresters, 2008). According to Jankowski (2018), forestry is referred to as the practice of managing forest lands for various uses, including commercial, agricultural, and public. Without forests, the planet would be an arid and empty space. The trees in the forest filter our air, provide nourishment and habitats for birds and wildlife. Therefore, forestry is the knowledge-based practice of managing the land of the forest, to be used for our protection, recreation, commercial and industrial purposes (Jankowski, 2018). Forestry is an important economic segment in various industrial countries. For instance, in Germany, forests cover nearly a third of the land area and supports more than a million jobs and about Euro181 billions of value to the German economy annually (Wald Eigentumer, 2016).

Livestock agriculture is concerned with raising and maintaining livestock primarily for the purposes of producing meat, milk, eggs, wool, leather, recreation (riding or racing) and draft (National Academy of Sciences, 2018). Livestock is vital to the economies of many developing countries. It provides food, income, employment and many other contributions to rural development and a source of foreign exchange for a nation. Livestock provide over half of the value of global agricultural output and one third in developing countries (Upton, 2014). 


\subsection{Theoretical Review}

\subsubsection{Structural Change Theory}

Lewis Arthur (1954) developed structural change theory which states that an economy is made up of two sectors agricultural sector and industrial sector. The two sectors are correlated. The agricultural sector employs inputs, labor expertise and is also a final consumer of the industrial sector output. On the other hand, the industrial sector employs labor and output of the agricultural sector. This theory centers on the mechanism by which underdeveloped economies can transform their domestic economic structures from a heavy emphasis on traditional subsistence agriculture to a more modern and progressive agricultural practice through heavy financial support that could help in achieving industrial advancement. The economic potential of agriculture goes well beyond farm fields, local food businesses and traditional supply chains. The Upstate Revitalization Initiative, or Southern Tier Soaring, seeks to build momentum in agriculture not just to create more local products and help our farm community thrive, but also because a strong agricultural base feeds into other employment sectors (Nyrop, 2017).

The application is that if all forms of agriculture is fully supported by the government through bank loans to farmers, fertilizer distribution, and training for existing and upcoming farmers, good roads and reduced transport cost for farm products, then consumption expenditure will be reduced. Small farmers will be able to increase productivity and expand their output. The growth of the economy will be at its peak and industries will equally thrive.

\subsection{Empirical Review}

Cervantes-Godoy and Dewbre (2010) employed a panel data of 25 countries which consist of the poorest and richest developing countries in the world from all geographic regions. These countries were found to be dissimilar in their governance systems and economic administration but are homogenous in a broad range of macroeconomic and agricultural economic performance in poverty reduction. This is why their comparison in the study was suitable. The data obtained were from 1980 to 2005 . The findings from the time-series and cross-sectional regression analysis revealed that growth in agricultural incomes contributed substantially to poverty reduction in the 25 countries.

Syed, Yasir, and Farhan (2012) used five sub-sectors of agricultural business in Pakistan to investigate the role of agriculture in economic growth of Pakistan. These agricultural sub-sectors include: major crops, minor crops, livestock, fisheries and forestry. The major crops consist of cotton, rice, wheat and sugarcane. The minor crops include: oil seeds, vegetables, pulses, chilies and other small crops. Livestock sector comprises cow, buffalos, goats, donkeys, horses and poultry. The study covered a period from 1980 to 2010 and made use of secondary form of data obtained from government authentic websites. The regression result revealed that crops and livestock contribute significantly to the economic performance of the country although fisheries and forestry have minimal or insignificant contribution to the economic performance of Pakistan. The reasons identified for the poor performance include: low investment in the sectors, insufficient facilities, untrained and unskillful labor compelled to go into fisheries and forestry farming.

Nazish et al. (2013) employed Johansen Co-integration to analyze the stability of the long run relationship among economic growth of Pakistan and the independent variables which are agriculture, manufacturing and services for a period of 31 years. The data used were secondary source and obtained from world development indicators from 1980 to 2010 . The findings revealed an existence of a stable long run relationship among the variables. The results of the study indicated that agriculture has the most significant contribution to the economy of Pakistan.

Odetola and Etumnu (2013) assessed the contribution of agriculture to economic growth in Nigeria using growth accounting framework and time series data from 1960 to 2011. All data used in the study were sourced from the Central Bank of Nigeria (CBN) Statistical Bulletin, 2011 edition. The study considered the four subsectors of agriculture in Nigeria which include: crop production, livestock, forestry and fisheries. The findings revealed that crop production has the highest contribution to economic growth in Nigeria and impacted most on agriculture sector growth. Despite the fact that livestock production sector is the second largest subsector, but the result revealed that fisheries sector contributes more to growth than the livestock. The study therefore, suggested increase in the productivity of other agricultural subsectors to avoid heavy reliance on crop production.

John Dunham and Associates (2017) assessed the impact of food and agriculture industries on US economy. The study made use of input-output analysis econometric techniques to examine the relationships of the selected variables within the US economy. The secondary source of data employed was obtained from published 
government data series available in the United States: Federal, State and County. The study established that food and agriculture industries are dynamic contributors to the US economy which accounts for about $20.4 \%$ of total national output, employ 43.31 million Americans who earned wages and benefits of about 1.99trillion USD. The industries member and their employees pay about $\$ 894.13$ billion taxes to the Federal, State and Local governments.

\subsection{Research Gap}

Studies on the contribution of agriculture to economic growth of a nation are inexhaustible. From the above literatures, it could be observed that this current study is actually on agriculture but with major variations on the subject matter, because it focuses on the role of agricultural subsectors in reducing consumption expenditure, in Nigeria. Syed et al. (2012) did a similar study in Pakistan from 1980-2010 using GDP as proxy for economic growth. This present study identifies that the primary aim of agriculture is to ensure availability of food for a nation's populace at a cheap and affordable rate. This is why the study measured the performance of agriculture subsectors in Nigeria using consumer price index (response variable) because it reflects the changes in the cost of goods and services. The study could be seen as the most recent study in this research area as it covers a period from 1981 to 2017 which is the immediate past year.

\section{Methodology}

The study is based on the role of agriculture in reducing the cost of living in Nigeria. Ex post facto research design is adopted based on the fact that all data employed are historical and are existing already. The explanatory variables used are the four sub-sectors of agriculture in Nigeria which include: crop production, fishing, forestry and livestock farming. The dependent variable is consumer price index (CPI) being proxy for consumption expenditure or cost of living in Nigeria. Time series data from 1981-2017 were obtained from the Central Bank of Nigeria (CBN) Statistical Bulletin, 2017 edition. The method of data analysis is the Ordinary Least Square (OLS) multiple regression technique with the aid of E-views version 9 econometric software. The statistical formulation of the model adapted with modification from Syed et al. (2012) is presented as follows:

$$
\mathrm{CPI}=\mathrm{f}(\mathrm{CPN}, \mathrm{FSG}, \mathrm{FSY}, \mathrm{LSK})
$$

The simple linear relationship is stated thus:

$$
\text { LOGCPI }=\beta_{0}+\beta_{1} \text { LOGCPN }+\beta_{2} \text { LOGFSG }+\beta_{3} \text { LOGFSY }+\beta_{4} \text { LOGLSK }+\mu
$$

Where:

$\begin{array}{ll}\text { CPI } & \text { Consumer Price Index } \\ \text { CPN } & \text { Crop production } \\ \text { FSG } & \text { Fishing } \\ \text { FSY } & \text { Forestry } \\ \text { LSK } & \text { Livestock } \\ \beta & \text { Intercept } \\ \beta_{1}-\beta_{4} & \text { Estimation Coefficients } \\ \mu & \text { Error term }\end{array}$

A Prior Expectation:

$\beta_{1}-\beta_{4}>0$

The economic expectations of all the predictor variables (CPN, FSG, FSY, and LSK) are to be positively greater than zero, by implication should have positive influence on the cost of living (CPI). 


\section{Data Analyses and Interpretation of Result}

Table 1. Unit root estimation

\begin{tabular}{lllllll}
\hline VARIABLE & AT LEVEL & & \multicolumn{4}{l}{ AT 1 ${ }^{\text {ST }}$ DIFFERENCE } \\
& ADF TEST & MACKINNON & P-VALUE & ADF TEST & MACKINNON & P-VALUE \\
& STATIS-TICS & CRITICAL VALUE & & STATIS-TICS & CRITICAL VALUE & \\
\hline CPI & -1.416724 & -2.967767 & 0.5603 & -3.453152 & -2.951125 & 0.0158 \\
CPN & -0.022922 & -2.945842 & 0.9502 & -5.821455 & -2.948404 & 0.0000 \\
FSG & 0.236774 & -2.957110 & 0.9708 & -9.068350 & -2.957110 & 0.0000 \\
FSY & 0.966684 & -2.948404 & 0.9953 & -6.087233 & -2.948404 & 0.0000 \\
LSK & 0.710605 & -2.948404 & 0.9907 & -4.124988 & -2.948404 & 0.0028 \\
\hline
\end{tabular}

Source: Authors' Computation, 2018.

Table 1 above shows the result of unit root test conducted on the time series data employed for the study. The test was carried out to prevent misleading regression result from the OLS technique when time series data are non-stationary. Therefore, in order to establish stationarity of the time series data, the study made use of Augmented Dickey-Fuller (ADF) unit root test. For the purpose of this study, the decision rule is that Mackinnon Critical Value at 5\% level of significance must be greater than the ADF test statistics. From table 1 above, all the variables were not stationary at levels but became stationary at first $\left(1^{\text {st }}\right)$ difference. At $1^{\text {st }}$ difference, the p-values are all less than 5\% and the Mackinnon critical values at 5\% level of significance are all greater than the ADF test statistics. Having established stationarity of the data set, then the regression result is considered reliable for estimation.

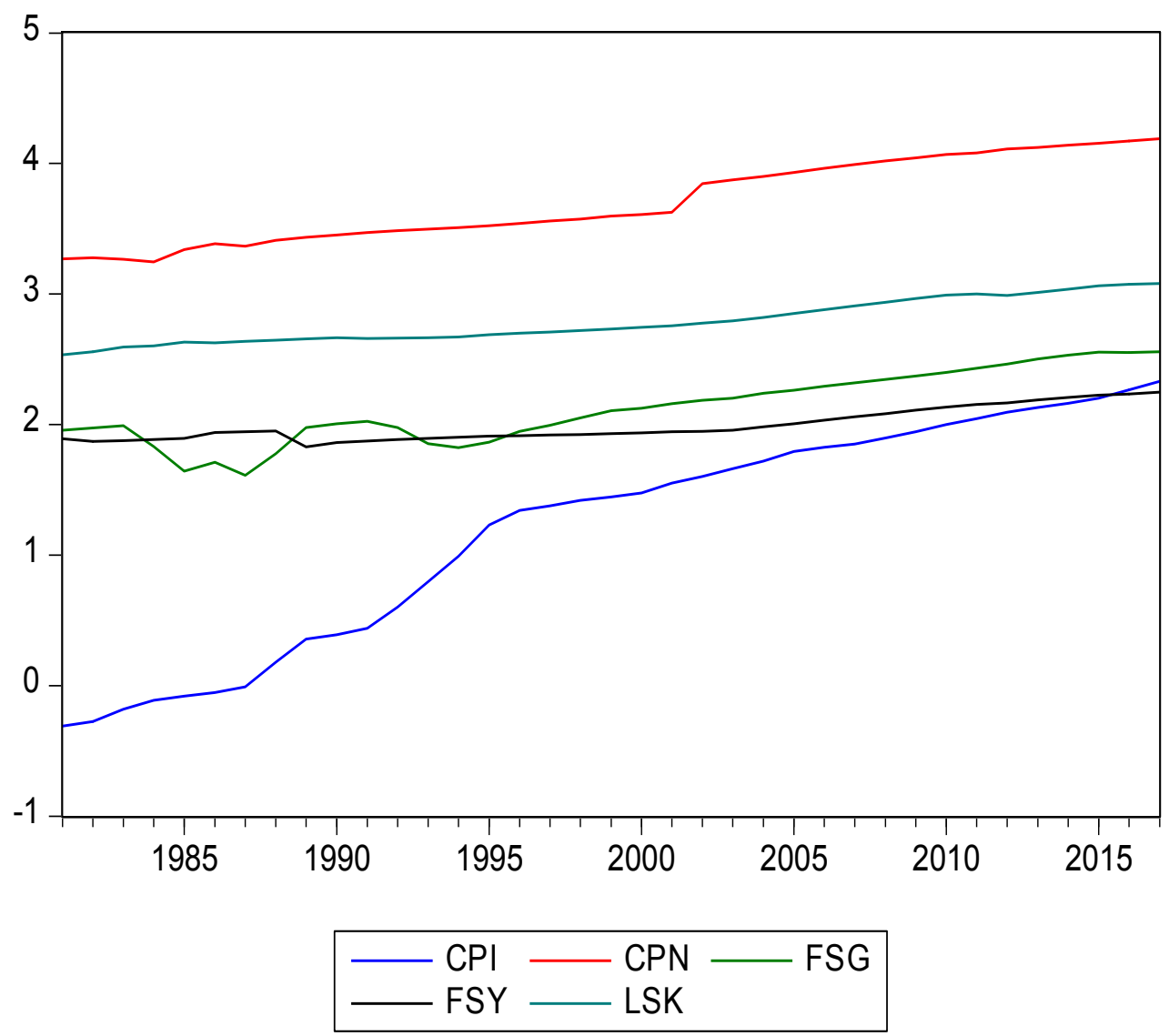

Figure 2. Trend of CPI and agriculture sub-sectors' output in Nigeria from 1981-2017

Source of data: CBN Statistical Bulletin, 2017. 
Figure 2 depicts the graphical representation of the trend of agriculture sub-sectors and the consumer price index (CPI). From the graph, crop production has the highest contribution, and then followed by livestock farming. From 2015 to 2017, forestry came below the CPI. This implies a negative impact on the cost of living. The fish farming contribution is not too fantastic but there was a slight steady growth from 2000 to 2017 . The implication of this whole analysis is that crop production has a leading trend in contributing to the economy of Nigeria. Although, livestock farming is coming up, but requires more effort and investment to maintain economic relevance. The fishing and forestry farming in Nigeria require adequate funding and cooperation to be economically viable.

Table 2. Regression results

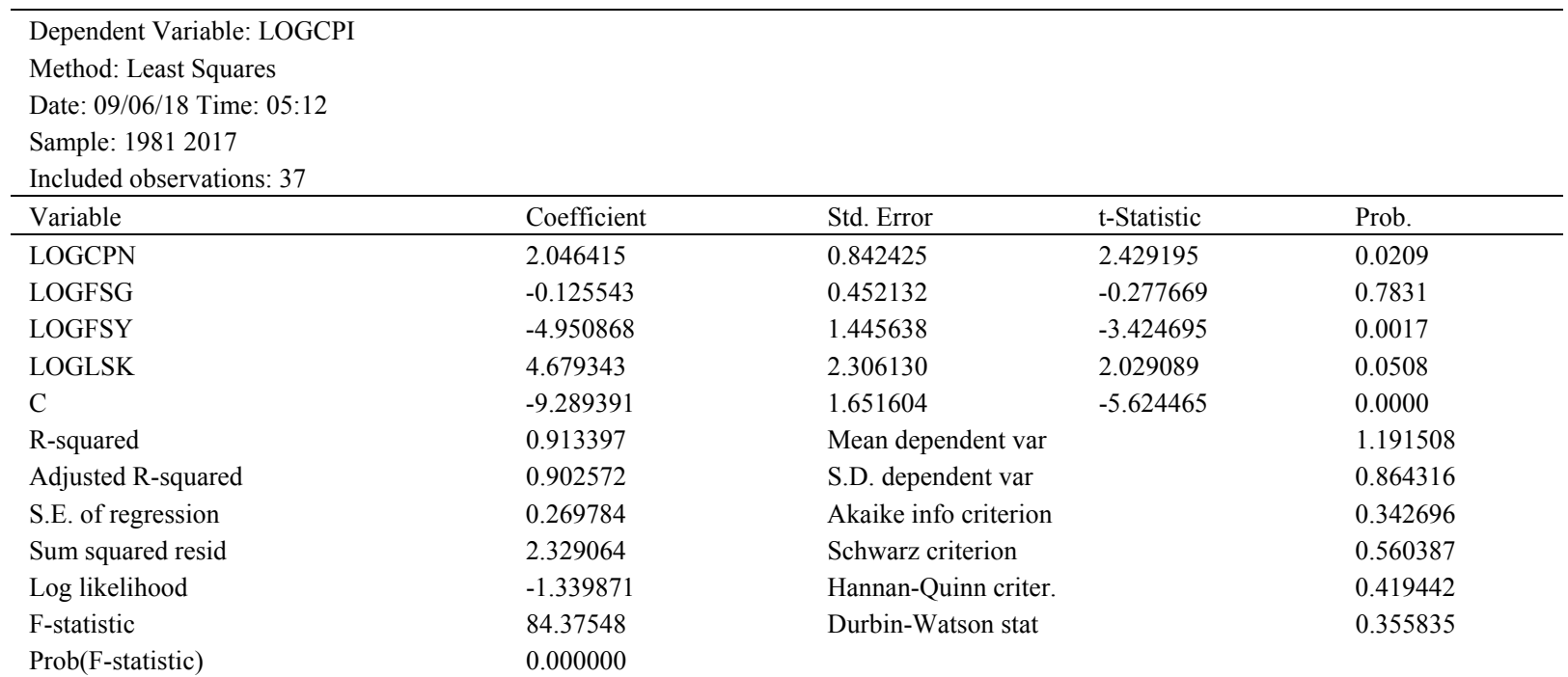

Source: Authors' Computation, 2018.

The regression result on table 2 shows that the correlation (R) value is $956 \%$ (square root of R-squared). This connotes a very high relationship between the dependent variable CPI and the independent variables (CPN, FSG, FSY and LSK). The R-squared value of $91.3 \%$ is also very high. The implication is that the independent variables explain about $91.3 \%$ of the changes in the dependent variable. Thus, it is only $8.5 \%$ of the variations that can be attributed to other factors not captured in the model. The F-statistic is 84.37548 with the p-value of $0.000<0.05$. This implies that the agriculture sub-sectors collectively impact on the cost of living positively and significantly. In other words, the model is statistically significant.

\subsection{Test of Hypotheses}

The study earlier hypothesized that agriculture subsectors (CPN, FSG, FSY and LSK) do not have significant influence on the cost of living in Nigeria. From the result on table 2 above, CPN has (t-statistics $=2.429195$; $\mathrm{P}$-value $=0.0209<0.05$ ). The result shows that CPN has a significant positive impact on CPI in Nigeria. In other words, crop production (CPN) contributes significantly in reducing consumption expenditure (CPI) in the country. Therefore, the Hol has been rejected and the alternative which states otherwise accepted. This result is in agreement with the findings of (Odetola \& Etumnu, 2013; Syed et al., 2012) whose studies revealed that crop production exerted positive and significant influence on the economic growth of Nigeria and Pakistan respectively.

The result also revealed that FSG has (t-statistics $=-0.277669$; P-value $=0.7831)$. This shows an insignificant negative impact of fishing on CPI. Therefore, Ho2 is accepted and the alternative rejected. The finding is in line with the study of (Odetola \& Etumnu, 2013; Syed et al., 2012) whose studies had empirical evidence the fishery farming did not impact positively and significantly on economic growth. FSY has (t-statistics $=-3.424695$; P-value $=0.0017)$. This result indicates that forestry in Nigeria has a significant negative impact on cost of living. In this case, Ho3 is accepted and the alternative rejected. This findings also complies with the study of (Odetola \& Etumnu, 2013; Syed et al., 2012). 
Finally, the result of LSK shows (t-statistics $=2.029089$; P-value $=0.05)$. The result implies that livestock farming in Nigeria is significantly and positively affecting reduction of cost of living. Therefore, Ho4 is hereby rejected and the alternative accepted. The findings of Syed et al. (2012) are in agreement with this result.

\subsection{Discussion on Findings}

From the regression result, the study's prior expectation is met by crop production and livestock farming while the fishing and forestry farming were below the economic expectation. The findings of this study agree with the empirical evidence of Syed et al. (2012) which revealed that crop production and livestock farming impacted positively and significantly on Pakistan economy. Though, the poor performance of fishing and forestry farming in Pakistan was attributed to low investment in the sectors, insufficient facilities and lack of expertise on the part of those forced to work in the sectors.

However in Nigeria, people work in these sectors out of the passion for it. Thus, the case of forced labor may not be the cause of poor performance. The reason may include, poor funding from the government as bank loans are difficult to access, lack of adequate training of the farmers, natural disasters such as bush burning, flood and droughts, followed by over grazing of forest lands. Lack of proper government policy and implementation on forestry business in Nigeria is also a limiting factor. Fish farming is limited by factors such as high cost of fish feeds, lack of clean water source, inadequate space and power supply.

\section{Conclusion and Recommendations}

The study provides an empirical evidence that crop production and livestock farming are the two major agriculture subsectors that have improved the Nigerian economy by minimizing the cost of living in the country. Although forestry and fish farming have not contributed positively in reducing consumption cost, therefore, the implication is that investment in these two agriculture sub-sectors is still inadequate.

Therefore, in line with the objectives of this research work, the study is recommending that the government should endeavor to encourage the farmers who are into crop production by subsidizing the cost of fertilizers and making them available at the right time. There should be adequate funding of all agriculture sub-sectors through free access to bank facilities by the farmers. Proper funding of forestry research and training by both the Federal and State governments is also suggested.

The study is also recommending legal backing for forest policy which should be enforceable where applicable. Fish farming should be well developed in the country with emphasis on reducing environmental pollution which tends to kill the fishes in the water. The government should try to reduce the high cost of fish feeds as well as providing electricity and clean water sources to encourage the farmers. The livestock farming in Nigeria requires a lot of funding to make their produce sufficient and affordable for the populace both rich and poor.

\section{References}

Agun, F. (2016). 10 Major challenges facing catfish farmers. Agri Farming. Retrieved from https://www.agricfarming.com/2016/01/10-major-challenges-facing-catfish.html

CBN. (2017). Central Bank of Nigeria (CBN) Statistical Bulletin, 2017 edition.

Cervantes-Godoy, D., \& Dewbre, J. (2010). Economic importance of agriculture for poverty Reduction. OECD Food, Agriculture and Fisheries Working Papers, No. 23, OECD Publishing.

FAO. (2018a). Fisheries. Food and Agriculture Organization (FAO) of the United Nations. Retrieved from www.fao.org/faoterm/collection/fisheries/en/

FAO. (2018b). Forest Industries of Nigeria. Retrieved from www.fao.org/docrep/004/ab592e/ab592e03.htm

Farmcrowdy. (2018). Best livestock farming practices to adopt. Retrieved from https://www.farmcrowdy.com/livestock-farming/

IMF. (2017). Nigeria - Consumer Price Index (2010 = 100). International Monetary Fund (IMF).

Jankowski, P. (2018). What is Forestry? Definition \& Types. Retrieved from https://study.com/Academy/lesson/what-is-forestry-definition-types.html

John Dunham and Associates. (2017). US Food and Agriculture Industries economic impact study. Feeding the economy, US food and agriculture industries. Retrieved from www.feedingtheeconomy.com/assets/res/methodology.pdf

Lewis, W. A. (1954). Economic development with unlimited supplies of labour. The Manchester School, 22(2), 115-227. https://doi.org/10.1111/j.1467-9957.1954.tb00021.x 
National Academy of Sciences. (2018). Livestock Agriculture and Animal feeding operations. Retrieved from https://www.nap.edu/

National Oceanic and Atmospheric Administration. (2006). Fisheries Glossary. United States Department of Commerce, NOAA. Retrieved from https://www.st.nmfs.noaa.gov/st4/documents/fishglossary.pdf

Nations Encyclopedia. (2018). Nigeria - $\quad$ Fishing. Retrieved from https://www.nationsencyclopedia.com/africa/nigeria.fishing.html

Nazish, A. R., Iqbal, A., \& Ramzan, M. (2013). Impact of agriculture, manufacturing and service Industry on the GDP growth of Pakistan. Interdisciplinary Journal of Contemporary Research in Business, 5(4), 727-734.

Nyrop, J. (2017). The economic impact of agriculture. Ithaca Journal, part of the USA Today Network. Retrieved from https://www.globalharvestinitiative.org/2018/01/american-Agriculture-drives-economic-growth/

Odetola, T., \& Etumnu, C. (2013). Contribution of Agriculture to Economic Growth in Nigeria. The $18^{\text {th }}$ Annual Conference of the African Econometric Society (AES) Accra, Ghana at the session organized by the Association for the Advancement of African Women Economists (AAAWE), July 22-23.

Society of American Foresters. (2008). The Dictionary of Forestry. Retrieved from https://web.archive.org

Steve, O. C. (2016). 9 Most profitable livestock farming/animal husbandry in Nigeria. Retrieved from https://www.africabusinessclassroom.com/livestock-farming-in-nigeria/

Steve, O. C. (2017). 11 Top Crops Farming and production in Nigeria, how to start and make Money. Retrieved from https://www.africabusinessclassroom.com/crops-farming-production-nigeria-start-make-money/

Syed, A. R., Yasir, A., \& Farhan, M. (2012). Role of agriculture in economic growth of Pakistan. International Research Journal of Finance and Economics, 83, 180-186.

The Economic Times. (2018). Definition of Consumer Price Index. Retrieved from https://Economictimes.indiatimes.com/definition/consumer-price-index

United Nations. (2008). International Standard Industrial Classification of All Economic Activities (ISIC), Rev. 4. Department of Economic and Social Affairs Statistic Division Series M No. 4, Rev. 4. United Nations Publication.

Upton, M. (2014). The role of livestock in economic development and poverty reduction. PPLPI Working paper No. 10. A living from livestock, FAO publication.

Wald Eigentumer. (2016). Unternehmen Wald. Retrieved from https://www.waldeigentuemer.De/themen/unternehmen-wald/

\section{Copyrights}

Copyright for this article is retained by the author, with first publication rights granted to the journal.

This is an open-access article distributed under the terms and conditions of the Creative Commons Attribution license (http://creativecommons.org/licenses/by/4.0/). 